\title{
Treatment options for small cell lung cancer - do we have more choice?
}

\author{
M Puglisi', S Dolly', A Faria', JS Myerson', S Popat' and MER O'Brien*,I \\ 'Department of Medicine, The Royal Marsden NHS Foundation Trust, Sutton, Surrey, UK
}

\begin{abstract}
Small cell lung cancer (SCLC) is a significant health problem worldwide because of its high propensity for relapse. This review discusses existing and future therapies for the treatment of SCLC. British Journal of Cancer (2010) I 02, 629-638. doi: I0.1038/sj.bjc.6605527 www.bjcancer.com

Published online 26 January 2010

(c) 2010 Cancer Research UK
\end{abstract}

Keywords: small cell lung cancer; chemotherapy; relapsed SCLC; treatment

Each year approximately 1.4 million people worldwide are diagnosed with lung cancer - $12 \%$ of all new cases of cancer. Small cell lung cancer (SCLC) now represents only $13 \%$ of all newly diagnosed lung cancers. The SEER database indicates that the annual incidence of SCLC has been decreasing over the past 30 years (Field and Duffy, 2008), More than $90 \%$ of patients with SCLC are current or past smokers, and the risk is related to the duration and intensity of the smoking (Brownson et al, 1992). The median age at diagnosis in developed countries is approximately 68 years, and as many as $31 \%$ of patients may be aged 70 years or older (Yau et al, 2006).

\section{STAGING}

The SCLC is an aggressive disease associated with early locoregional and distant metastases and paraneoplastic syndromes (Lally et al, 2007). It has a different staging system to that of other solid tumours (Chua et al, 2004). The Veterans Affairs Administration Lung Cancer Study Group (VALG) two-stage classification system introduced in 1957 the terms limited disease (LD) and extensive disease (ED) (Felip et al, 2005). Thirty years later, the consensus report of the International Association of Lung Cancer (IASLC) modified the VALG classification (Stahel et al, 1989). They recommended including patients with ipsilateral and contralateral, hilar, mediastinal and supraclavicular nodes' as LD. They also included patients with ipsilateral pleural effusion regardless of the cytology in the limited subgroup.

A Japanese series reported the comparison of a group of patients who received definitive thoracic radiotherapy (TRT) in which the pleural effusion had disappeared after induction chemotherapy, with a second group who did not receive TRT despite response and a third group with a pleural effusion that did not respond to

\footnotetext{
* Correspondence: Dr M O'Brien, The Royal Marsden NHS Foundation Trust, Downs Road, Sutton, Surrey SM2 5PT, UK.

E-mail: mary.obrien@rmh.nhs.uk

Received 30 April 2009; revised 2 December 2009; accepted 8 December 2009; published online 26 January 2010
}

chemotherapy. Long-term survival was achieved in those patients who successfully underwent chemoradiotherapy (Niho et al, 2008).

An ongoing retrospective survival analysis of data from $>8000$ SCLC patients in the IASLC database, many of whom were treated surgically, showed that survival of patients with LD and effusion is intermediate between those of patients with LD without effusion and patients with ED. The data suggest that clinical TNM staging can identify subgroups of patients with distinct prognoses within the conventional definition of LD and that all effusion should be cytologically proven (Shepherd et al, 2007). Such findings have led to the new recommendations for lung cancer staging based on the AJCC/UICC TNM seventh edition that are likely to supersede the VALG system in future clinical trials of SCLC (Detterbeck et al, 2009).

\section{PROGNOSTIC FACTORS}

Disease stage remains the most powerful prognostic factor for SCLC. The Manchester scoring system is frequently used in the clinic as an indicator of prognosis in SCLC. It is calculated from a number of physical and biochemical markers, including serum lactate dehydrogenase, serum sodium concentration, serum alkaline phosphatase, serum bicarbonate, Karnofsky performance status (PS) and stage of disease (Cerny et al, 1987). Prognosis for patients with SCLC is poor, even in those with early stage (nonmetastatic) SCLC. From the time of diagnosis, the median ranges of survival for LD-SCLC and ED-SCLC are 15-20 and 8-13 months, respectively. Approximately $20-40 \%$ of patients with LDSCLC and $5 \%$ of patients with ED-SCLC survive for 2 years (Lally et al, 2007).

\section{TREATMENT OF LIMITED STAGE}

The survival of patients with LD-SCLC has improved over the past 20 years, with a 5 -year survival rate of $13.9 \%$ compared with $6 \%$ before 2000 in our own institution - the Royal Marsden Hospital (Figure 1). The positive outcome in LD seems to be multifactorial, with better staging, platinum-based chemotherapy and the use of prophylactic cranial irradiation (PCI) all exerting an effect. The 


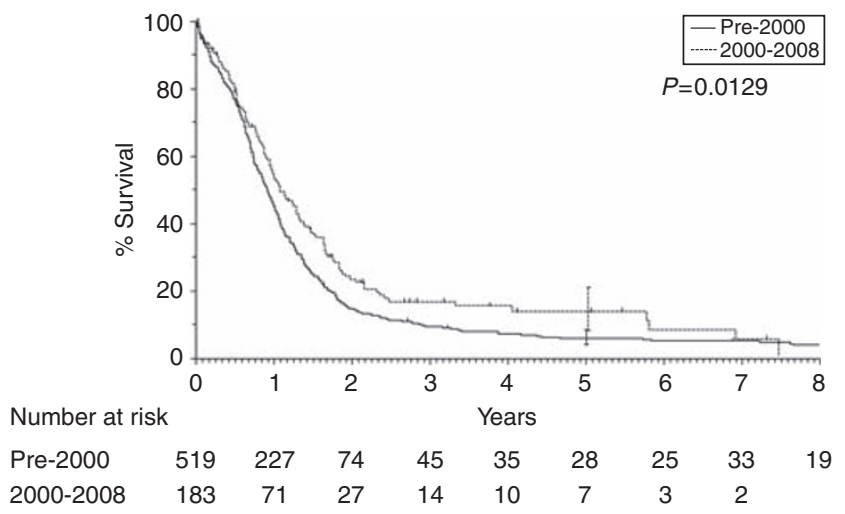

Figure I Survival rates of patients with LD-SCLC pre-2000: 5-year survival 13.9\% vs 6.1\%; 2 -year survival 17\% vs $27 \%$. (Unpublished data from the Royal Marsden Hospital, UK.)

addition of TRT to chemotherapy, both sequentially and, more recently, concomitantly, significantly reduces the risk of intrathoracic failures, resulting in improvements in long-term survival in this population (Pignon et al, 1992).

\section{Surgery}

The function of surgery has never been fully developed because of the apparent failure of this treatment modality in two randomised trials reported in 1976 and 1994. Both trials did not show any survival advantage for surgery alone or in combination with TRT, compared with radiotherapy alone (Fox and Scadding, 1973; Lad et al, 1994). A recent review of these data suggests that the 'intention to treat' results may have misrepresented the effect of surgery, as not all patients randomised to surgery and included in the analyses actually underwent a complete resection. In fact, only $48 \%$ and $77 \%$ of patients, respectively, did so, meaning that the impact of surgery may have been underestimated.

A more recent retrospective analysis of surgery for patients with stage I-IIIB at the Royal Brompton Hospital reported a 5-year progression-free survival (PFS) of $46 \%$ (Lim and Goldstraw, 2008). Other published prospective series also suggest that surgery, after induction chemotherapy, can achieve high local control rates in early stage SCLC (stage I-III) with favourable long-term survival results (Fujimori et al, 1997; Eberhardt et al, 1999). The survival rates reported are higher than the historical control, with $63 \%$ and $46 \%$ of patients alive at 3 and 5 years, respectively. To validate this hypothesis, a number of randomised trials have recently been designed to compare surgery, in combination with chemotherapy or chemoradiotherapy, with the current standard of treatment with chemoradiotherapy using modern staging methods.

\section{Chemoradiation}

Combined modality therapy with chemotherapy and thoracic irradiation is the current accepted standard for patients with LDSCLC (NCCN, 2008). Two meta-analyses have established the function of TRT in the management of patients with LD (Pignon et al, 1992; Warde and Payne, 1992). Both reports found an improved intrathoracic tumour control rate with combined modality patients and statistically improved survival with an absolute benefit in overall survival (OS) at 3 years (Pignon et al, 1992) and 2 years (Warde and Payne, 1992) of 5.4\%. Treatmentrelated toxicity is worse with combination treatments, but is acceptable in patients with a good PS.

There are a number of unresolved issues in the delivery of chemotherapy and radical radiotherapy in LD-SCLC including timing of TRT, early $v s$ late, concomitant or sequential, total dose and fractionation schedule. Many trials have addressed the timing issues, but they have differed in trial design as well as the chemotherapy regimen used as reviewed recently by Socinski and Stinchcombe (2007).

A number of meta-analyses have shown a modest survival benefit with early compared with delayed concurrent TRT, most notably in combination with a cisplatin-based regimen (Fried et al, 2004; Huncharek and McGarry, 2004; Socinski and Stinchcombe, 2007). Additional analyses indicate that the overall treatment time for TRT, as well as the time of TRT initiation, influences survival. A Cochrane review of seven trials observed a significant survival benefit at 5 years for patients who had early radiotherapy delivered within an overall treatment time of 30 days (Pijls-Johannesma et al, 2005). A second analysis found that patients who received their last dose of TRT $<30$ days after the first dose of chemotherapy had a significantly greater likelihood of survival at 5 years compared with completion of TRT $>30$ days after chemotherapy initiation (De Ruysscher et al, 2006).

A landmark study by Turrisi et al (1999) showed that a hyperfractionation regimen of $45 \mathrm{~Gy}$ given twice daily over a 3week period was associated with significantly improved OS at 5 years compared with $45 \mathrm{~Gy}$ once daily over 5 weeks ( $26 \%$ vs $16 \%$; $P=0.04)$. Tolerability was comparable between the groups, although osophagitis was reported significantly more frequently in the twice-daily dosing group. Relapse rates in patients given once-daily TRT were significantly higher leading to the suggestion that patients in this arm were under-dosed. A trial has recently commenced comparing $45 \mathrm{~Gy}$ twice daily in $1.5 \mathrm{~Gy}$ fractions $v s$ $66 \mathrm{~Gy}$ once daily in $2 \mathrm{~Gy}$ fractions that should provide further guidance on optimisation and standardisation of radiotherapy for LD-SCLC (Faivre-Finn and Falk, 2009).

It should be noted that EP remains the only chemotherapy that can be delivered at full dose in combination with radiotherapy in LD-SCLC.

\section{TREATMENT OF ED}

Chemotherapy is the main treatment for ED-SCLC. Treatments in the past including oral etoposide, standard- and high-dose regimens have been extensively reviewed by the authors in an earlier publication (Popat and O'Brien, 2005). Combination therapy with EP is considered the standard first-line regimen (Sundstrom et al, 2002), but a randomised Phase III trial failed to prove a definitive survival benefit for EP compared with the cyclophosphamide, doxorubicin and vincristine regimen (CAV) (Roth et al, 1992). In a recent trial (Sundstrom et al, 2002), a significant survival advantage in favour of the EP arm was seen for LD patients, but only a trend in survival benefit was seen in the ED group, with a median survival of 8.4 months as compared with 6.5 months in the CAV arm $(P=0.21)$. The recently published Cochrane review in SCLC concluded that there was no statistical survival benefit from platinum-based regimens. There was an improvement in complete response rates, which is important in $\mathrm{LD}$; however, there was greater toxicity in terms of emesis, anaemia and thrombocytopaenia. LD-SCLC and ED-SCLC were not separated. The review highlights the lack of quality-of-life (QoL) data. Major differences in QoL between an anthracycline and platinum-based regimen are not expected with modern powerful anti-emetics, and the haematological toxicities of anaemia and thrombocytopaenia can be managed (Amarasena et al, 2008). It is unlikely that a head-to-head study will be repeated with QoL assessment at this point in time.

A randomised Phase III study of EP $v s$ carboplatin and etoposide (CE) showed no differences in response and survival between the two treatment arms, although the study was not powered for non-inferiority (Skarlos et al, 1994). A more recent randomised trial comparing split doses of EP vs CE in elderly or 
Table I Phase II/III studies of combination chemotherapy in patients with ED-SCLC

\begin{tabular}{|c|c|c|c|c|c|c|c|c|}
\hline \multirow{3}{*}{$\begin{array}{l}\text { Author } \\
\text { Noda et al (2002) }\end{array}$} & \multirow{3}{*}{$\begin{array}{l}\text { Staging } \\
\text { ED }\end{array}$} & \multirow{3}{*}{$\frac{\text { Patients (n) }}{154}$} & \multicolumn{2}{|c|}{ Experimental regimen } & \multirow{2}{*}{$\begin{array}{l}\text { Standard regimen } \\
\text { Schedule }\end{array}$} & \multicolumn{3}{|c|}{ Outcomes } \\
\hline & & & & Schedule & & \multicolumn{2}{|c|}{ Overall survival (months) } & \multirow{2}{*}{$\begin{array}{l}\mathbf{R R} \\
+\mathrm{re}\end{array}$} \\
\hline & & & $\begin{array}{l}\text { Irinotecan/ } \\
\text { cisplatin }\end{array}$ & $\begin{array}{l}\text { I: } 60 \mathrm{mg} / \mathrm{m}^{-2} \text { days } 1,8,15 \\
\text { P: } 60 \mathrm{mg} \mathrm{m}^{-2} \text { day I; } \mathrm{q} 4 \mathrm{w}\end{array}$ & $\begin{array}{l}\text { E: } 100 \mathrm{mg} \mathrm{m}^{-2} \text { days } 1,2,3 \\
\text { P: } 80 \mathrm{mgm}^{-2} \text { day I; } \mathrm{q} 3 w\end{array}$ & I 2.8 vs 9.4 months & +ve & \\
\hline Hanna et al (2006a) & $E D$ & 331 & & $\begin{array}{l}\text { I: } 65 \mathrm{mg} \mathrm{m}^{-2} \text { days I, } 8 \\
\text { P: } 30 \mathrm{mg} \mathrm{m}^{-2} \text { days I, } 8 \text {; q3w }\end{array}$ & $\begin{array}{l}\mathrm{E}: 120 \mathrm{mg} \mathrm{m}^{-2} \text { days } 1,2,3 \\
\mathrm{P}: 60 \mathrm{mg} \mathrm{m}^{-2} \text { day I; q3w }\end{array}$ & 9.3 vs 10.2 months & NS & NS \\
\hline Lara et al (2009) & $E D$ & 645 & & $\begin{array}{l}\text { I: } 60 \mathrm{mg} \mathrm{m}^{-2} \text { days I, } 8,15 \\
\text { P: } 60 \mathrm{mg} \mathrm{m}^{-2} \text { day I; } q 4 \mathrm{w}\end{array}$ & $\begin{array}{l}\text { E: } 100 \mathrm{mg} \mathrm{m}^{-2} \text { days } 1,2,3 \\
\text { P: } 80 \mathrm{mg} \mathrm{m}^{-2} \text { day } 1 ; \text { q } 3 w\end{array}$ & 9.9 vs 9.1 months & NS & NS \\
\hline Hermes et al (2008) & ED & 220 & $\begin{array}{l}\text { Irinotecan/ } \\
\text { carboplatin }\end{array}$ & $\begin{array}{l}\text { I: } 175 \mathrm{mg} \mathrm{m}^{-2} \text { day I } \\
\text { Ca: AUC } 4 \text { day I; q3w }\end{array}$ & $\begin{array}{l}\text { E: } 120 \mathrm{mg} \mathrm{m}^{-2} \text { orally days } 1-5 \\
\text { Ca: AUC } 4 \text { day I; } q 3 w\end{array}$ & 8.5 vs 7.1 months & +ve & I \\
\hline Socinski et al (2009) & ED & 733 & $\begin{array}{l}\text { Pemetrexed/ } \\
\text { carboplatin }\end{array}$ & $\begin{array}{l}\text { Pe: } 500 \mathrm{mg} \mathrm{m}^{-2} \text { day I } \\
\text { Ca: AUC } 5 \text { day I; q3w }\end{array}$ & $\begin{array}{l}\text { E: } 100 \mathrm{mg} \mathrm{m}^{-2^{\prime}} \text { days } 1,2,3 \\
\text { Ca: AUC } 5 \text { day I; } q 3 w\end{array}$ & 7.29 vs 9.56 months & $-v e$ & $-v e$ \\
\hline Niell et al (2005) & ED & 587 & $\begin{array}{l}\text { Paclitaxel/ } \\
\text { etoposide/ } \\
\text { cisplatin }\end{array}$ & $\begin{array}{l}\text { Pa: } 175 \mathrm{mg} \mathrm{m}^{-2} \text { day I } \\
\text { E: } 80 \mathrm{mg} \mathrm{m}^{-2} \text { days I-3 } \\
\text { P: } 80 \mathrm{mg} \mathrm{m}^{-2} \text { day I; q } 3 \mathrm{w}\end{array}$ & $\begin{array}{l}\mathrm{E}: 80 \mathrm{mg} \mathrm{m}^{-2} \text { days I, } 2,3 \\
\mathrm{P}: 80 \mathrm{mg} \mathrm{m}^{-2} \text { day I; q3w }\end{array}$ & I0.6 vs 9.9 months & NS & + ve \\
\hline Mavroudis et al (200I) & ED, LD & 133 & & $\begin{array}{l}\text { Pa: } 175 \mathrm{mg} \mathrm{m}^{-2} \text { day I } \\
\text { E: } 80 \mathrm{mg} \mathrm{m}^{-2} \text { days I - } 4 \\
\text { P: } 80 \mathrm{mg} \mathrm{m}^{-2} \text { day } 2 ; \mathrm{q} 3 \mathrm{w}\end{array}$ & $\begin{array}{l}\text { E: } 120 \mathrm{mg} \mathrm{m}^{-2} \text { days I, } 2,3 \\
\text { P: } 80 \mathrm{mg} \mathrm{m}^{-2} \text { day I; q3w }\end{array}$ & 9.5 vs 10.5 months & NS & NS \\
\hline Heigener et al (2008) & $E D$ & 795 & $\begin{array}{l}\text { Topotecan/ } \\
\text { cisplatin }\end{array}$ & $\begin{array}{l}\text { T: I } \mathrm{mg} \mathrm{m}^{-2} \text { days I-5 } \\
\text { P: } 75 \mathrm{mg} \mathrm{m}^{-2} \text { day I; q3w }\end{array}$ & $\begin{array}{l}\text { E: } 100 \mathrm{mg} \mathrm{m}^{-2} \text { days I, } 2,3 \\
\text { P: } 75 \mathrm{mg} \mathrm{m}^{-2} \text { day I; q3w }\end{array}$ & 10.3 vs 9.4 months & Non-inferior & $+\mathrm{ve}$ \\
\hline Eckardt et al (2006) & ED & 784 & & $\begin{array}{l}\mathrm{T}: 1.7 \mathrm{mg} \mathrm{m}^{-2} \text { oral days I -5 } \\
\mathrm{P}: 60 \mathrm{mg} \mathrm{m}^{-2} \text { day } 5 ; \mathrm{q} 3 \mathrm{w}\end{array}$ & $\begin{array}{l}\mathrm{E}: 100 \mathrm{mg} \mathrm{m}^{-2} \text { days I, } 2,3 \\
\text { P: } 80 \mathrm{mg} \mathrm{m}^{-2} \text { day I; } \mathrm{q} 3 \mathrm{w}\end{array}$ & 39.3 vs 40.3 weeks & Non-inferior & NS \\
\hline Lee et al (2009) & $\begin{array}{l}\text { ED, LD, poor } \\
\text { prognoses }\end{array}$ & 241 & $\begin{array}{l}\text { Gemcitabine/ } \\
\text { carboplatin }\end{array}$ & $\begin{array}{l}\text { G: } 1200 \mathrm{mg} \mathrm{m}^{-2} \text { days I, } 8 \\
\text { Ca: AUC } 5 \text { day I; q3w }\end{array}$ & $\begin{array}{l}\mathrm{E}: 120 \mathrm{mg} \mathrm{m}^{-2} \text { day } 1 ; 100 \mathrm{mg} \mathrm{m}^{-2} \\
\text { bd orally days } 2,3 \\
\text { P: } 60 \mathrm{mg} \mathrm{m}^{-2} \text { day I; } \mathrm{q} 3 \mathrm{w}\end{array}$ & 8 vs 8.1 months & Non-inferior & NS \\
\hline
\end{tabular}

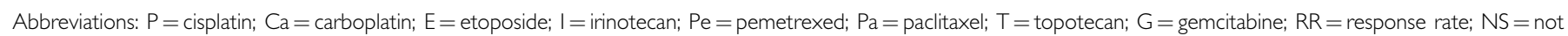
significant; $A \cup C=$ area under the curve; $E D=$ extensive disease; $L D=$ limited disease; $S C L C=$ small cell lung cancer.

poor-risk patients with ED-SCLC also failed to show any significant difference in response rate or survival (Okamoto et al, 2007). Given these data, several cytotoxic drugs identified as active against SCLC have been tested in combination with cisplatin or carboplatin (Table 1).

A study conducted by the Japan Clinical Oncology Group showed a significant survival benefit for irinotecan and cisplatin combination vs EP (Noda et al, 2002), but a second study in US patients of the same agents failed to show any significant difference (Hanna et al, 2006a). A recent pharmacogenomic analysis of Japanese and US patients treated with carboplatin and paclitaxel for non-SCLC revealed that differences in outcomes for survival and toxicity could be explained by genotypic variations between the two nationalities (Gandara et al, 2009). The investigators found significant differences between Japanese and US patients in the frequency of variant alleles for genes encoding enzymes involved in paclitaxel metabolism and DNA repair. Exploratory analyses revealed significant associations between some of these variant alleles and patients' treatment response and survival. A similar genetic basis may explain the different responses to irinotecan and cisplatin in SCLC. Indeed, it is established that the variety in allelic distribution of enzymes involved in irinotecan metabolism differ between Japanese and Caucasian patients (Ando et al, 2002).

Topotecan has shown significant anti-tumour activity and symptom palliation in relapsed SCLC. The doublet oral topotecan plus cisplatin (TC) showed both similar benefit and toxicity to EP. Grades 3 and 4 neutropaenia were more frequent with EP (84\%vs $59 \%)$, whereas TC caused a higher rate of anaemia (38\% vs $21 \%)$, thrombocytopaenia ( $38 \%$ vs $23 \%$ ) and diarrhoea ( $33 \%$ vs $18 \%)$, but a lower rate of alopecia (TC 24\% vs PE 40\%) (Eckardt et al, 2006; Heigener et al, 2008).

Two Phase III randomised studies have investigated the possible function of paclitaxel in SCLC by adding paclitaxel to the platinum/etoposide doublet. Both trials led to similar conclusions and failed to show a benefit in survival for the experimental arm, but reported an increase in haematological and non-haematological toxicity, and a higher rate of toxicity-related death (Mavroudis et al, 2001; Niell et al, 2005).
A Phase III trial, evaluating pemetrexed and carboplatin, which was closed after a planned interim analysis showed inferior PFS in the experimental arm compared with the standard etoposide and platinum combination (Socinski et al, 2009).

A non-inferiority trial was designed to determine whether gemcitabine plus carboplatin (GC) would be less toxic, and associated with better QoL when compared with EP chemotherapy. The GC chemotherapy achieved survival rate, response rate and time to progression equivalent to EP. The two regimens had a different toxicity profile; a higher rate of grades $2-3$ nausea and alopecia occurred in EP-treated patients, whereas more frequent grades 3 and 4 haematological toxicity were seen with the GC schedule (Lee et al, 2009). A more realistic comparison would have been GC and CE, and a comparative study of these combinations would be of interest. The GC regimen is useful, particularly in patients with mixed small cell and non-small cell tumours, and for those for whom alopecia is a real problem.

To summarise these results, all the recent randomised trials using later generation cytotoxics have not had a significant impact on standard care for SCLC, failing to identify a new platinumbased combination over the established platinum etoposide.

\section{NEW AGENTS AND ONGOING RESEARCH}

Amrubicin is a synthetic anthracycline and a potent topoisomerase II inhibitor approved in Japan for the treatment of SCLC. As a first-line therapy for $\mathrm{ED}$, amrubicin in combination with cisplatin achieved an impressive response rate of $88 \%$ and a median OS of 13.6 months in Japan (Ohe et al, 2005). Clinical trials are ongoing in the United States and Europe to determine whether amrubicin will be effective in other ethnic groups.

Targeted agents are also an area of considerable interest given their success in other tumour types. The SCLC has been identified as a highly angiogenic tumour and a number of pro-angiogenic circulating factors have been implicated in this disease. Thalidomide has anti-angiogenic properties and has been investigated earlier in combination with first-line chemotherapy and as maintenance therapy in Phase II trials (Dowlati et al, 2007; 
Lee et al, 2008). However, two large randomised Phase III trials have failed to show any benefit for thalidomide plus chemotherapy over chemotherapy alone (Pujol et al, 2007; Lee et al, 2009). In the most recent studies, an analysis of data from over 700 patients failed to show any difference in OS or PFS between the groups, but did show a significant increase in the risk of thrombotic events with thalidomide (Lee et al, 2009).

Maintenance therapy with vandetanib (ZD6474), a VEGF receptor tyrosine kinase inhibitor, did not increase OS or PFS when compared with placebo (Arnold et al, 2007). In addition, bevacizumab in first-line treatment of SCLC - in combination with either cisplatin and etoposide or cisplatin and irinotecan - has not yielded results as promising as was expected (Ready et al, 2007; Sandler et al, 2007); however, further results are awaited. Taken together, these data suggest that targeting angiogenesis in SCLC with current approaches may not work as well as in other tumour types.

Increased understanding of the molecular mechanism of tumour resistance to apoptosis has led to the development of promising targeted therapies, which selectively modulate pro- and antiapoptotic proteins. Small molecule inhibitors of $b c l-2$ family antiapoptotic members are currently under evaluation in Phase I and II trials. The first Phase II trial with the $b c l-2$ anti-sense oligonucleotide oblimersen as initial therapy for ED-SCLC has been negative, suggesting worse outcome for patients receiving oblimersen in association with $\mathrm{CE}$, compared with $\mathrm{CE}$ alone. The response rates were the same in both treatment arms $(61 \%$ vs $60 \%$ ), whereas the percentage of patients alive at 1 year was $24 \%$ with oblimersen and $47 \%$ without oblimersen (Rudin et al, 2008).

To date, none of the new-targeted agents investigated have been found to alter the clinical history of SCLC.

\section{Prophylactic cranial irradiation}

Approximately $14-24 \%$ of patients with SCLC have detectable brain metastases (BM) at the time of initial diagnosis (Argiris and Murren, 2001). Data regarding the efficacy of chemotherapy in patients with brain relapse is scanty, although responses do occur (Postmus et al, 1989, 1995; Groen et al, 1993). Survival after metastasis to the brain is short, ranging from about 3 to 5 months (Postmus et al, 1998, 2000).

Trials conducted in the late 1980s and early 1990s, and two subsequent meta-analyses, have confirmed that PCI significantly improves survival for patients with SCLC who achieved a complete response (using chest X-rays) after induction treatment, with an absolute improvement in OS of $5.4 \%$ at 3 years (Auperin et al, 1999; Prophylactic-Cranial-Irradiation-Overview-CollaborativeGroup, 2000). As revealed by a CT scan, PCI is also now offered to patients with a good partial response.

The function of PCI in patients with ED-SCLC after chemotherapy has recently been investigated in a randomised Phase III trial conducted by the EORTC lung group (Slotman et al, 2007). The incidence of symptomatic BM, the primary objective of the trial, was significantly reduced after PCI in patients who did not progress on initial systemic therapy. The cumulative risk of metastases at 1 year was $14.6 \%$ in the PCI arm compared with $40.4 \%$ in the control arm. The median survival increased from 5.4 to 6.7 months after randomisation, and the 1 -year survival rate was $27.1 \%$ in the irradiation group and $13.3 \%$ in the control group. However, it should be noted that brain imaging was not conducted in this trial before randomisation unless patients displayed symptoms indicative of BM. Nevertheless, a recent UK survey reports quick implementation of PCI in patients with ED-SCLC in radiotherapy centres based on the EORTC data (Bayman et al, 2008, 2009).

\section{TREATMENT OPTIONS FOR RELAPSED SCLC}

Despite high initial response rates to chemotherapy, SCLC usually recurs within 1 year after treatment (Ardizzoni, 2004). It is estimated that $80 \%$ of patients with LD, and almost all patients with ED, relapse or experience disease progression (Clark and Ihde, 1998). As the prognosis is poor, symptom palliation and maintenance of QoL are important therapeutic goals in the relapsed setting (Gralla, 2004; Nicum and O'Brien, 2007).

\section{Chemotherapy options}

On the basis of retrospective data, distinction has been made between (1) sensitive patients, that is those with a response to firstline therapy and a treatment-free interval of at least 90 days, (2) resistant patients, that is relapse within 90 days and (3) refractory patients, that is no response to first-line treatment (Vincent et al, 1988; Fischer and Arcaro, 2008). The PS and sensitivity to initial chemotherapy were found to be prognostic and predictive variables for chemotherapy outcome in recurrent SCLC patients (Kim et al, 2008). The relevance of these categories has recently been called into question with respect to re-treatment decisions (O’Brien et al, 2006).

The CAV may be used after first-line treatment with EP, with a response rate of $8-28 \%$ (von Pawel et al, 1999). A trial of the Norwegian lung cancer study group has evaluated the benefit of crossover chemotherapy with $\mathrm{CAV}$ at relapse after primary treatment with EP, compared with EP at relapse after CAV. There was no survival difference between the two crossover treatment groups (median survival after relapse was 3.9 and 4.5 months, respectively), and no differences in outcomes were observed in either resistant or sensitive patients. Nevertheless, these data are from a selected subgroup of patients, because only a limited number of patients $(42 \%)$ from the initial-treated population were considered to be suitable for second-line chemotherapy at the time of disease progression. Moreover, a comparison between the second-line chemotherapy and the best supportive care group, in a non-randomised design, revealed a significantly better survival rate in favour of the chemotherapy group, although this difference could be explained by more negative prognostic factors in the best supportive care group (Sundstrom et al, 2005).

Single-agent topotecan is currently the only approved drug for the treatment of patients with SCLC who have failed or relapsed after first-line chemotherapy. Topotecan is available in both intravenous and oral formulations and randomised studies have suggested that both have similar clinical activity in SCLC (von Pawel et al, 2001; Eckardt, 2003). A randomised Phase III trial has shown significant benefit with oral topotecan plus best supportive care $v s$ best supportive care only in relapsed patients unsuitable for intravenous regimens (Table 2). The OS was significantly longer in the topotecan group (median survival 25.9 vs 13.9 weeks), and survival was preserved in patients with a short time to progression after first-line therapy (60 days) and in those with a PS score of 2. Moreover, patient QoL and symptom control was significantly greater in patients who received topotecan (O'Brien et al, 2006). A randomised trial comparing intravenous topotecan with the CAV regimen observed comparable response rates $(24.3 \%$ and $18.3 \%$, respectively) and median survival (25.0 and 24.7 weeks), although topotecan was associated with greater symptom improvement in terms of improved dyspnoea, anorexia, fatigue, insomnia and daily activity (von Pawel et al, 1999).

\section{Other evaluated drugs}

Over the past years, several cytotoxic agents, including taxanes, gemcitabine, vinorelbine and irinotecan, have been investigated for second-line treatment, as either single agent or combination (Table 3). Out of the many Phase II trials, with a relatively small number of patients and uneven distribution of sensitive $v s$ refractory disease, some agents, such as paclitaxel, irinotecan 
Table 2 Randomised trials for the treatment of relapsed SCLC

Results

\begin{tabular}{|c|c|c|c|c|c|c|c|c|c|c|}
\hline \multirow[b]{2}{*}{ Authors } & \multirow[b]{2}{*}{ Study type } & \multirow[b]{2}{*}{ Regimen } & \multirow[b]{2}{*}{ Schedule } & \multirow[b]{2}{*}{ Patients ( $n$ ) } & \multicolumn{4}{|c|}{ Response rate (\%) } & \multirow{2}{*}{$\begin{array}{l}\text { Median TTP } \\
\text { (weeks) }\end{array}$} & \multirow{2}{*}{$\begin{array}{c}\text { Median survival } \\
\text { (weeks) }\end{array}$} \\
\hline & & & & & ORR & CR & $\mathbf{P R}$ & SD & & \\
\hline \multirow[t]{2}{*}{$\begin{array}{l}\text { von Pawel et al } \\
\text { (1999) }\end{array}$} & $\begin{array}{l}\text { Randomised } \\
\text { Phase II }\end{array}$ & CAV vs topotecan & $\begin{array}{l}\text { Cyclophosphamide } 1000 \mathrm{mg} \mathrm{m}^{-2}+ \\
\text { doxorubicin } 45 \mathrm{mg} \mathrm{m}^{-2}+\text { vincristine } \\
2 \mathrm{mg} \mathrm{m}^{-2} \text {, day I, q3w }\end{array}$ & 104 & 18.3 & । & 18 & 12 & - & 24.7 \\
\hline & & & IV topotecan: $1.5 \mathrm{mg} \mathrm{m}^{-2}$, days $\mathrm{I}-5, \mathrm{q} 3 \mathrm{w}$ & 107 & 24.3 & 0 & 26 & 21 & - & 25.0 \\
\hline \multirow[t]{2}{*}{$\begin{array}{l}\text { von Pawel et al } \\
(200 \mathrm{I})\end{array}$} & $\begin{array}{l}\text { Randomised } \\
\text { Phase II }\end{array}$ & $\begin{array}{l}\text { Oral topotecan vs IV } \\
\text { topotecan }\end{array}$ & Oral topotecan: $2.3 \mathrm{mg} \mathrm{m}^{-2}$, days $\mathrm{I}-5$, q3w & 52 & 23 & 2 & 21 & 19 & 14.9 & 32 \\
\hline & & & IV topotecan: $1.5 \mathrm{mg} \mathrm{m}^{-2}$, days $\mathrm{I}-5, \mathrm{q} 3 \mathrm{w}$ & 54 & 15 & 4 & 11 & 30 & 13.1 & 25 \\
\hline \multirow[t]{2}{*}{ Eckardt (2007) } & $\begin{array}{l}\text { Randomised } \\
\text { Phase III }\end{array}$ & $\begin{array}{l}\text { Oral topotecan vs IV } \\
\text { topotecan }\end{array}$ & Oral topotecan: $2.3 \mathrm{mg} \mathrm{m}^{-2}$, days $1-5, \mathrm{q} 3 \mathrm{w}$ & 153 & 18 & - & - & 18 & - & 33 \\
\hline & & & IV topotecan: $1.5 \mathrm{mg} \mathrm{m}^{-2}$ days $1-5, \mathrm{q} 3 \mathrm{w}$ & 151 & 22 & - & - & 23 & - & 35 \\
\hline \multirow[t]{2}{*}{$\begin{array}{l}\text { O'Brien et al } \\
(2006)\end{array}$} & $\begin{array}{l}\text { Randomised } \\
\text { Phase III }\end{array}$ & $\begin{array}{l}\text { Oral topotecan } \\
+ \text { BSC vs BSC alone }\end{array}$ & Oral topotecan: $2.3 \mathrm{mg} \mathrm{m}^{-2}$, days $1-5, \mathrm{q} 3 \mathrm{w}$ & 71 & 7 & 0 & 7 & 44 & 16.3 & 25.9 \\
\hline & & & BSC alone & 70 & - & - & - & - & - & 13.9 \\
\hline
\end{tabular}

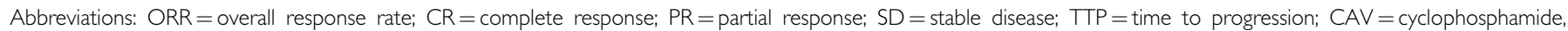
doxorubicin and vincristine; $\mathrm{BSC}=$ best supportive care; $\mathrm{SCLC}=$ small cell ling cancer.

Table 3 Clinical studies of targeted agents for the treatment of SCLC

\begin{tabular}{|c|c|c|c|c|c|c|c|c|}
\hline \multirow[b]{2}{*}{ Authors } & \multirow[b]{2}{*}{$\begin{array}{l}\text { Targeted } \\
\text { agent }\end{array}$} & \multirow[b]{2}{*}{$\begin{array}{l}\text { Combination } \\
\text { regimen }\end{array}$} & \multirow[b]{2}{*}{$\begin{array}{l}\text { Targeted } \\
\text { population }\end{array}$} & \multirow[b]{2}{*}{ Phase } & \multirow[b]{2}{*}{$\begin{array}{l}\text { Sample } \\
\text { size }\end{array}$} & \multicolumn{2}{|r|}{ Result } & \multirow[b]{2}{*}{ Conclusion } \\
\hline & & & & & & $\mathbf{R R}$ & OS/PFS (months) & \\
\hline \multicolumn{9}{|l|}{ TKs inhibitors } \\
\hline Dy et al (2005) & Imatinib & - & $\begin{array}{l}\text { Relapsed, resistant/ } \\
\text { sensitive }[\mathrm{c}-\text { Kit }+]\end{array}$ & $\|$ & 29 & $\begin{array}{l}\text { No PR } \\
\text { No SD }\end{array}$ & $\begin{array}{l}\text { OS: } R=3.9 \\
S=5.3\end{array}$ & No clinical activity \\
\hline Krug et al (2005) & & - & $\begin{array}{l}\text { Relapsed, resistant/ } \\
\text { sensitive }[\mathrm{c}-\text { Kit }+]\end{array}$ & $\|$ & 12 & $\begin{array}{l}\text { No PR } \\
\text { No SD }\end{array}$ & OS: 2 & No clinical activity \\
\hline Johnson et al (2003) & & - & $\begin{array}{l}\text { ES, untreated relapsed, } \\
\text { sensitive }\end{array}$ & $\|$ & 19 & No PR & - & No clinical activity \\
\hline Schneider et al (2006) & & - & $\begin{array}{l}\text { ES, if no PD after l-line } \\
\mathrm{IP} \times 4[\mathrm{c}-\text { Kit }+]\end{array}$ & $\|$ & 14 & No PR & OS: 10 & $\begin{array}{l}\text { Disease stability not } \\
\text { maintained }\end{array}$ \\
\hline Spigel et al (2007) & & Carboplatin/irinotecan & $\mathrm{ES}$, untreated & $\|$ & 69 & PR 66\% & OS: 8.4 & $\begin{array}{l}\text { No improvement in results } \\
\text { from chemotherapy alone }\end{array}$ \\
\hline Moore et al (2006) & Gefitinib & - & $\begin{array}{l}\text { Relapsed, resistant/ } \\
\text { sensitive }\end{array}$ & $\|$ & 19 & No PR $10 \%$ SD & OS: 206 days & No clinical activity \\
\hline \multicolumn{9}{|l|}{ Anti-angiogenic agents } \\
\hline Sandler et al (2007) & Bevacizumab & Cisplatin/etoposide & ES, untreated & $\|$ & 64 & OR $69 \%$ & PFS at 6 months: $33 \%$ & Promising results \\
\hline Ready et al (2007) & & Irinotecan/cisplatin & $\mathrm{ES}$, untreated & $\|$ & 72 & $\begin{array}{l}\text { CR 3\% } \\
\text { PR } 71 \%\end{array}$ & OS: 11.7 & $\begin{array}{l}\text { Primary end point not } \\
\text { reached }\end{array}$ \\
\hline Jalal et al (2008) & & Paclitaxel & Relapsed, sensitive & $\|$ & 34 & $\begin{array}{l}\text { PR I I\% } \\
\text { SD } 55 \%\end{array}$ & OS: 21 weeks & Active regimen \\
\hline Pujol et al (2007) & Thalidomide & PCDE & $\begin{array}{l}\mathrm{ES} \text {, after response to } \\
\mathrm{PCDE} \times 2\end{array}$ & III & 119 & - & OS: I I.7/8.7 (NS) & $\begin{array}{l}\text { Thalidomide did not } \\
\text { improve survival }\end{array}$ \\
\hline Lee et al (2008) & & Carboplatin/etoposide & $\mathrm{ES}$ and $\mathrm{LS}$, untreated & III & 724 & - & OS: $10.2 / 10.5$ (NS) & $\begin{array}{l}\text { Thalidomide did not } \\
\text { improve survival }\end{array}$ \\
\hline Gitlitz et al (2008) & Sorafenib & - & $\begin{array}{l}\text { Relapsed (platinum- } \\
\text { treated) }\end{array}$ & $\|$ & 81 & $\begin{array}{l}\text { PR } 4 \% \\
\text { SD } 32 \%\end{array}$ & $\begin{array}{l}-7, S \\
-5, R\end{array}$ & Clinical activity \\
\hline Ramalingam et al (2008) & $\begin{array}{l}\text { Cediranib } \\
(Z D 2|7|)\end{array}$ & - & $\begin{array}{l}\text { Relapsed (platinum- } \\
\text { treated) }\end{array}$ & $\|$ & 25 & $\begin{array}{l}\text { PR: I patient } \\
\text { SD: } 9 \text { patients }\end{array}$ & PFS 1.2 & No clinical activity \\
\hline Arnold et al (2007) & $\begin{array}{l}\text { Vandetanib } \\
\text { (ZD6474) }\end{array}$ & - & $\begin{array}{l}\text { ES and } L S \text {, untreated. } \\
\text { If no PD after first-line } \\
\text { platinum-based (and } \\
\text { PCI/TRT) }\end{array}$ & $\|$ & 107 & - & PFS and OS NS & $\begin{array}{l}\text { No efficacy as maintenance } \\
\text { therapy }\end{array}$ \\
\hline
\end{tabular}

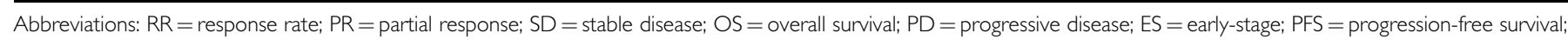

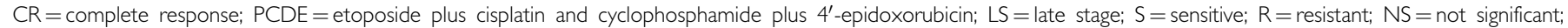
$\mathrm{PCl}=$ prophylactic cranial irradiation; TRT $=$ thoracic radiotherapy; $\mathrm{OR}=$ overall response.

and temozolamide, have shown some degree of activity. Nevertheless, the lack of comparative trials prevents any formal conclusions.

Pemetrexed (Table 4), recently tested in three Phase II studies, has shown minimal activity in relapsed SCLC patients. High-dose pemetrexed can be given without significant increase in serious toxicities, but this does not seem to increase efficacy (Hanna et al, 2006b; Gronberg et al, 2008; Socinski et al, 2008).

\section{New agents and ongoing research}

As well as in first-line chemotherapy, amrubicin have shown impressive results for the second-line treatment of relapsed SCLC. High response rates (between $37 \%$ and $60 \%$ ) have been reported for single-agent amrubicin in three Phase II Japanese studies conducted in a population with sensitive and resistant relapses (Kato et al, 2006; Kudoh et al, 2006; Onoda et al, 2006). The overall 
Table 4 Evaluated drugs in relapsed SCLC

\begin{tabular}{|c|c|c|c|c|c|c|c|c|}
\hline \multirow[b]{2}{*}{ Drug } & \multirow[b]{2}{*}{ Dose/schedule } & \multirow[b]{2}{*}{ Authors } & \multirow[b]{2}{*}{ Population } & \multirow[b]{2}{*}{ Phase } & \multirow[b]{2}{*}{ Patients (n) } & \multicolumn{2}{|c|}{ Results } & \multirow[b]{2}{*}{ Conclusion } \\
\hline & & & & & & Response (\%) & os & \\
\hline \multirow[t]{3}{*}{ Gemcitabine } & $1250 \mathrm{mg} \mathrm{m}^{-2}$ days I, 8; q3w & Hoang et al (2003) & Se, Rs, $\operatorname{Re}$ & $\|$ & 27 & No response & 6.4 months & Limited activity \\
\hline & $1000 \mathrm{mg} \mathrm{m}^{-2}$ days I, 8, 15; q4w & van der Lee et al (200I) & $\begin{array}{l}\text { Rs, } \operatorname{Re}(76 \%>1 \\
\text { earlier line) }\end{array}$ & $\|$ & 41 & $13 \%$ & 17 weeks & Modest activity \\
\hline & $1000 \mathrm{mg} \mathrm{m}^{-2}$ days $1,8,15 \mathrm{q} 4 \mathrm{w}$ & Masters et al (2003) & Se, Rs, Re & $\|$ & 46 & $11.9 \%$ & 7.1 months & Modest activity \\
\hline Irinotecan & $100 \mathrm{mg} \mathrm{m}^{-2}$ weekly & Masuda et al (1992) & Se, Rs, Re & $\|$ & 16 & $47 \%$ & 6.8 months & Active agent \\
\hline \multirow[t]{2}{*}{ Paclitaxel } & $175 \mathrm{mgm}^{-2} ; \mathrm{q} 3 \mathrm{w}$ & Smit et al (1998) & Rs & $\|$ & 24 & $29 \%$ & 100 days & Active agent \\
\hline & $200 \mathrm{mgm}^{-2} ; \mathrm{q} 3 \mathrm{w}$ & Joos et al (2004) & Rs, Re & $\|$ & 44 & $20 \%$ & 4 months & Active agent \\
\hline \multirow[t]{2}{*}{ Vinorelbine } & $25 \mathrm{mg} \mathrm{m}^{-2}$ weekly & Furuse et al (1996) & Se, Rs, $\operatorname{Re}$ & $\|$ & 24 & $12.5 \%$ & - & Modest activity \\
\hline & $30 \mathrm{mg} \mathrm{m}^{-2}$ weekly & Jassem et al (1993) & $\mathrm{Se}$ & $\|$ & 26 & $16 \%$ & - & Modest activity \\
\hline \multirow[t]{3}{*}{ Pemetrexed } & $500 \mathrm{mg} \mathrm{m}^{-2} ; \mathrm{q} 3 \mathrm{w}$ & Hanna et al (2006b) & Se, Rs & $\|$ & 43 & $\begin{array}{l}\text { Se: I PR } \\
\text { Rs: I PR }\end{array}$ & - & Minimal activity \\
\hline & $900 \mathrm{mg} \mathrm{m}^{-2} ; \mathrm{q} 3 \mathrm{w}$ & Gronberg et al (2008) & Se, Rs & $\|$ & 34 & $\begin{array}{l}\text { Se: } 4.5 \% \\
\text { Rs: } 2.9 \%\end{array}$ & 17.6 weeks & Limited activity \\
\hline & $900 \mathrm{mg} \mathrm{m}^{-2} ; \mathrm{q} 3 \mathrm{w}$ & Socinski et al (2008) & Se, Rs & $\|$ & 121 & $0.9 \%(\mathrm{I} P R$ in $\mathrm{Se})$ & $2.5-6.1$ months & Minimal activity \\
\hline \multirow[t]{5}{*}{ Amrubicin } & $40 \mathrm{mg} \mathrm{m}^{-2}$ days I-3; q3w & Onoda et al (2006) & Se, Rs & $\|$ & 60 & $\begin{array}{l}\text { Se OR: } 52 \% \\
\text { Rs OR: } 50 \%\end{array}$ & $\begin{array}{l}\text { Se: } 11.6 \text { months } \\
\text { Rs: } 10.3 \text { months }\end{array}$ & Significant activity \\
\hline & $45 \mathrm{mg} \mathrm{m}^{-2}$ days $1-3 ; \mathrm{q} 3 \mathrm{w}$ & Kato et al (2006) & Se, Rs & $\|$ & 35 & $\begin{array}{l}\text { Se OR: } 50 \% \\
\text { Rs OR: } 60 \%\end{array}$ & 8.8 months & Significant activity \\
\hline & $40 \mathrm{mg} \mathrm{m}^{-2}$ days I $-3 ; \mathrm{q} 3 \mathrm{w}$ & Kudoh et al (2006) & $\mathrm{Se}, \mathrm{Rs}$ & $\|$ & 19 & OR: $37 \%$ & - & Active agent \\
\hline & $40 \mathrm{mg} \mathrm{m}^{-2}$ days I-3; q3w & Ettinger et al (2008) & Rs, Re & $\|$ & 63 & PR: $13 / 39$ & - & Active agent \\
\hline & $\begin{array}{l}\text { Amrubicin: } 40 \mathrm{mg} \mathrm{m}^{-2} \text { days } \mathrm{I}-3 \text {; } \\
\text { q3w } \\
\text { Topotecan: I } \mathrm{mg} \mathrm{m}^{-2} \text { days } \mathrm{I}-5\end{array}$ & Inoue et al (2008) & Se, Rs & $\|$ & 60 & $38 \%$ vs $13 \%$ & - & $\begin{array}{l}\text { Amrubicin may be } \\
\text { superior to topotecan }\end{array}$ \\
\hline Picoplatin & $150 \mathrm{mg} \mathrm{m}^{-2} ; \mathrm{q} 3 \mathrm{w}$ & Bentzion et al (2007) & $\mathrm{Se}, \mathrm{Rs}, \mathrm{Re}$ & $\|$ & 77 & - & 28.1 weeks & $\begin{array}{l}\text { Compares favourably with } \\
\text { other therapeutic options }\end{array}$ \\
\hline
\end{tabular}

Abbreviations: $O S=$ overall survival; $\mathrm{Se}=$ sensitive (initially responded and then relapsed/progressed between 60 and I 80 days); Rs $=$ resistant (initially responded to first-line platinum-containing chemotherapy and then relapsed/progressed within 60-90 days); Re = refractory (failed or progressed with first-line platinum-containing chemotherapy); $\mathrm{PR}=$ partial response; $\mathrm{OR}=$ overall response.

median survival was 11.2 and 8.8 months for sensitive and resistant patients, respectively (Kato et al, 2006; Onoda et al, 2006). Interestingly, the response rate and the median survival time were similar in both sensitive and resistant patients (Table 4). A US Phase II trial has investigated single-agent amrubicin in patients with refractory or resistant SCLC (Ettinger et al, 2008). Activity was observed and the most frequent toxicity was myelosuppression, but no classic anthracycline-induced cardiotoxicity has been observed.

A randomised Phase II trial has compared amrubicin and topotecan in earlier treated SCLC. This study further supports the efficacy of amrubicin in both sensitive (overall response rate of $53 \%$ ) and resistant patients (overall response rate of $17 \%$ ). A higher response rate was achieved with amrubicin compared with topotecan (Inoue et al, 2008). This Japanese study unfortunately used topotecan at a dose of $1 \mathrm{mg} \mathrm{m}^{-2}$ rather than the current recommended dose of $1.5 \mathrm{mg} \mathrm{m}^{-2}$. Preliminary results of a second Phase II trial seem to confirm a trend in favour of amrubicin over topotecan as single-agent chemotherapy for sensitive relapsed SCLC in terms of response rate, but PFS was not statistically different. Further evaluations are currently ongoing within a Phase III setting.

At present, a second drug is under investigation in a Phase III setting. Picoplatin is a platinum analogue with some activity in relapsed SCLC, as shown in an earlier Phase II trial conducted in refractory, resistant and sensitive patients (Eckardt et al, 2009). The Phase III study evaluates picoplatin plus best supportive care $v s$ best supportive care alone in both refractory and relapsed patients (SPEAR trial).

Targeted therapy is currently being explored in relapsed SCLC. Some of the first agents investigated as second-line therapy were imatinib and gefitinib; however, both agents were unsuccessful (Table 3). Current research is now focused on angiogenesis inhibitors (Table 3).

From preliminary results of a Phase II trial, bevacizumab in combination with paclitaxel in chemosensitive relapsed SCLC seems to be an active regimen (Jalal et al, 2008). Cediranib, a highly potent inhibitor of VEGFR-1, -2 and -3 , has also shown limited anti-cancer activity as monotherapy in chemosensitive relapsed patients (Ramalingam et al, 2008).

Sorafenib and sunitinib are multikinase inhibitors acting on pathways involved in tumour progression and angiogenesis, and are both undergoing investigation for the treatment of SCLC in either the first- or second-line setting. The only data available so far are on sorafenib, which seems to be a promising agent with a median survival of 7 and 5 months in platinum-sensitive and platinum-refractory patients, respectively (Gitlitz et al, 2008). This compared favourably with historical controls receiving salvage chemotherapy. A Phase I trial of weekly topotecan in combination with sorafenib in treatment of relapsed SCLC has been commenced.

NKH-1 (or CD56) is a neural adhesion molecule that is highly expressed in SCLC (Fischer and Arcaro, 2008). The immunotoxin N901-bR is a murine monoclonal antibody directed against CD56. $\mathrm{Hu}$ 901-DM1 is an immunoconjugate created by the conjugation of the maytansinoid drug DM 1 to a humanised version of the murine monoclonal antibody N901. At a dose of $60 \mathrm{mg} \mathrm{m}^{-2}$ per week, 2 out of 10 patients with relapsed SCLC obtained a partial response and another one a minor response; this study is ongoing (Fossella et al, 2005).

\section{Proteosome inhibitors}

Bortezomib targets the ubiquitin-proteosome pathway interfering with p21, p27, p53, cyclins D, E and A, nuclear factor $\kappa \mathrm{B}$ and members of the Bax family. In a Phase II trial using bortezomib at a dose of $1.3 \mathrm{mg} \mathrm{m}^{-2}$ on Days $1,4,8$ and 11 every 21 days, only one partial response was obtained. Further studies are, therefore, underway to assess the benefit of combining bortezomib with topotecan in the second-line setting (Johl et al, 2005). 


\section{CONCLUSION}

The SCLC is a significant healthcare problem worldwide because of its aggressive nature and high propensity for relapse. Combination chemotherapy continues to be the mainstay of SCLC treatment in the first-line setting; the combination of cisplatin or carboplatin with etoposide is the most commonly used regimen. Despite relatively high initial response rates, most patients with SCLC eventually relapse, but treatment options for patients with relapsed SCLC are limited. Topotecan is currently the only approved single-agent for second-line therapy and recent data with oral topotecan show that more of these patients than suggested earlier can achieve further responses, symptom control and survival prolongation.

A number of other chemotherapeutic agents, including irinotecan, paclitaxel and amrubicin, have shown some activity in small Phase II/III trials when used as monotherapy or in combination with other cytotoxic agents. Recent progress in the understanding of the biology of SCLC has led to the identification of crucial

\section{REFERENCES}

Amarasena IU, Walters JA, Wood-Baker R, Fong K (2008) Platinum versus non-platinum chemotherapy regimens for small cell lung cancer. Cochrane Database Syst Rev 4: CD006849

Ando M, Ando Y, Sekido Y, Ando M, Shimokata K, Hasegawa Y (2002) Genetic polymorphisms of the UDP-glucuronosyltransferase 1A7 gene and irinotecan toxicity in Japanese cancer patients. Jpn J Cancer Res 93: $591-597$

Ardizzoni A (2004) Topotecan in the treatment of recurrent small cell lung cancer: an update. Oncologist 9(Suppl 6): 4-13

Argiris A, Murren JR (2001) Staging and clinical prognostic factors for small-cell lung cancer. Cancer J 7: 437-447

Arnold AM, Seymour L, Smylie M, Ding K, Ung Y, Findlay B, Lee CW, Djurfeldt M, Whitehead M, Ellis P, Goss G, Chan A, Meharchand J, Alam Y, Gregg R, Butts C, Langmuir P, Shepherd F (2007) Phase II study of vandetanib or placebo in small-cell lung cancer patients after complete or partial response to induction chemotherapy with or without radiation therapy: National Cancer Institute of Canada Clinical Trials Group Study BR.20. J Clin Oncol 25: 4278-4284

Auperin A, Arriagada R, Pignon JP, Le Pechoux C, Gregor A, Stephens RJ, Kristjansen PE, Johnson BE, Ueoka H, Wagner H, Aisner J (1999) Prophylactic cranial irradiation for patients with small-cell lung cancer in complete remission. Prophylactic Cranial Irradiation Overview Collaborative Group. $N$ Engl J Med 341: 476-484

Bayman N, Lorigan P, Blackhall F, Faivre-Finn C (2008) Radiotherapy in extensive-disease small cell lung cancer. Surv Curr UK Pract 21(1): 78

Bayman N, Lorigan P, Blackhall F (2009) Faivre-Finn C. Clin Oncol ( $R$ Coll Radiol) 21(1): 78

Brownson RC, Chang JC, Davis JR (1992) Gender and histologic type variations in smoking-related risk of lung cancer. Epidemiology 3: 61-64

Cerny T, Blair V, Anderson H, Bramwell V, Thatcher N (1987) Pretreatment prognostic factors and scoring system in 407 small-cell lung cancer patients. Int J Cancer 39: $146-149$

Chua YJ, Steer C, Yip D (2004) Recent advances in management of smallcell lung cancer. Cancer Treat Rev 30: $521-543$

Clark R, Ihde DC (1998) Small-cell lung cancer: treatment progress and prospects. Oncology (Williston Park) 12: 647-658; discussion $661-3$

De Ruysscher D, Pijls-Johannesma M, Bentzen SM, Minken A, Wanders R, Lutgens L, Hochstenbag M, Boersma L, Wouters B, Lammering G, Vansteenkiste J, Lambin P (2006) Time between the first day of chemotherapy and the last day of chest radiation is the most important predictor of survival in limited-disease small-cell lung cancer. J Clin Oncol 24: $1057-1063$

Detterbeck FC, Boffa DJ, Tanoue LT (2009) The new lung cancer staging system. Chest 136: $260-271$

Dowlati A, Subbiah S, Cooney M, Rutherford K, Mekhail T, Fu P, Chapman R, Ness A, Cortas T, Saltzman J, Levitan N, Warren G (2007) Phase II| trial of thalidomide as maintenance therapy for extensive stage small cell lung cancer after response to chemotherapy. Lung Cancer 56: $377-381$

Dy GK, Miller AA, Mandrekar SJ, Aubry MC, Langdon Jr RM, Morton RF, Schild SE, Jett JR, Adjei AA (2005) A phase II trial of imatinib (ST1571) signalling pathways and the subsequent development of targeted therapies. Several novel molecules are presently undergoing evaluation, and represent potential future additions to the treatment repertoire for SCLC.

\section{ACKNOWLEDGEMENTS}

We accept sole responsibility for the accuracy of the manuscript, and also had final responsibility for the decision to submit for publication. We also acknowledge NHS funding to the NIHR Biomedical Research Centre.

\section{Conflict of interest}

This article was supported by GlaxoSmithKline. M O’Brien has performed paid lectures and consultancies for GlaxoSmithKline and Celgene. in patients with c-kit expressing relapsed small-cell lung cancer: a CALGB and NCCTG study. Ann Oncol 16: 1811-1816

Eberhardt W, Stamatis G, Stuschke M, Wilke H, Muller MR, Kolks S, Flasshove M, Schutte J, Stahl M, Schlenger L, Budach V, Greschuchna D, Stuben G, Teschler H, Sack H, Seeber S (1999) Prognostically orientated multimodality treatment including surgery for selected patients of smallcell lung cancer patients stages IB to IIIB: long-term results of a phase II trial. Br J Cancer 81: $1206-1212$

Eckardt JR (2003) Topotecan in relapsed small-cell lung cancer: can good things come in small packages? Clin Lung Cancer 4: 229-230

Eckardt JR, Bentsion DL, Lipatov ON, Polyakov IS, Mackintosh FR, Karlin DA, Baker GS, Breitz HB (2009) Phase II study of picoplatin as secondline therapy for patients with small-cell lung cancer. J Clin Oncol 27: 2048-2051

Eckardt JR, von Pawel J, Papai Z, Tomova A, Tzekova V, Crofts TE, Brannon S, Wissel P, Ross G (2006) Open-label, multicenter, randomized, phase III study comparing oral topotecan/cisplatin versus etoposide/cisplatin as treatment for chemotherapy-naive patients with extensive-disease small-cell lung cancer. J Clin Oncol 24: 2044-2051

Eckardt JR, von Pawel J, Pujol JL, Papai Z, Quoix E, Ardizzoni A, Poulin R, Preston AJ, Dane G, Ross G (2007) Phase III study of oral compared with intravenous topotecan as second-line therapy in small-cell lung cancer. J Clin Oncol 25: 2086-2092

Ettinger DS, Jotte RM, Gupta V, Allen AR, Oliver JW (2008) A phase II trial of single-agent amrubicin (AMR) in patients with extensive disease small cell lung cancer (ED-SCLC) that is refractory or progressive within 90 days of completion of first-line platinum-based chemotherapy. J Clin Oncol 26. Abstract 8041

Faivre-Finn C, Falk S (2009) CONVERT: concurrent once-daily versus twice-daily radiotherapy - a new phase III randomised controlled trial for patients with limited-stage small cell lung cancer and good performance status. Lung Cancer 63: S12

Felip E, Pavlidis N, Stahel RA (2005) ESMO minimum clinical recommendations for diagnosis, treatment and follow-up of small-cell lung cancer (SCLC). Ann Oncol 16(Suppl 1): i30-i31

Field JK, Duffy SW (2008) Lung cancer screening: the way forward. $\mathrm{Br} \mathrm{J}$ Cancer 99: $557-562$

Fischer B, Arcaro A (2008) Current status of clinical trials for small cell lung cancer. Rev Recent Clin Trials 3: 40-61

Fossella F, McCann J, Tolcher A, Xie H, Hwang L, Carr C, Berg K, Fram R (2005) Phase II trial of BB-10901 (huN901-DM1) given weekly for four consecutive weeks every 6 weeks in patients with relapsed SCLC and CD56-positive small cell carcinoma. J Clin Oncol 23. Abstract 7159

Fox W, Scadding JG (1973) Medical Research Council comparative trial of surgery and radiotherapy for primary treatment of small-celled or oat-celled carcinoma of bronchus. Ten-year follow-up. Lancet 2: $63-65$

Fried DB, Morris DE, Poole C, Rosenman JG, Halle JS, Detterbeck FC, Hensing TA, Socinski MA (2004) Systematic review evaluating the timing 
of thoracic radiation therapy in combined modality therapy for limitedstage small-cell lung cancer. J Clin Oncol 22: 4837-4845

Fujimori K, Yokoyama A, Kurita Y, Terashima M (1997) A pilot phase 2 study of surgical treatment after induction chemotherapy for resectable stage I to IIIA small cell lung cancer. Chest 111: 1089-1093

Furuse K, Kubota K, Kawahara M, Takada M, Kimura I, Fujii M, Ohta M, Hasegawa K, Yoshida K, Nakajima S, Ogura T, Niitani H, Japan Lung Cancer Vinorelbine Study Group (1996) Phase II study of vinorelbine in heavily previously treated small cell lung cancer. Oncology 53: 169-172

Gandara DR, Kawaguchi T, Crowley J, Moon J, Furuse K, Kawahara M, Teramukai S, Ohe Y, Kubota K, Williamson SK, Gautschi O, Lenz HJ, McLeod HL, Lara Jr PN, Coltman Jr CA, Fukuoka M, Saijo N, Fukushima M, Mack PC (2009) Japanese-US common-arm analysis of paclitaxel plus carboplatin in advanced non-small-cell lung cancer: a model for assessing population-related pharmacogenomics. J Clin Oncol 27: $3540-3546$

Gitlitz BJ, Glisson BS, Moon J, Reimers H, Gandara DR (2008) Sorafenib in patients with platinum (plat) treated extensive stage small cell lung cancer (E-SCLC): a SWOG (S0435) phase II trial. J Clin Oncol 26. Abstract 8039

Gralla RJ (2004) Quality-of-life considerations in patients with advanced lung cancer: effect of topotecan on symptom palliation and quality of life. Oncologist 9 (Suppl 6): 14-24

Groen HJ, Smit EF, Haaxma-Reiche H, Postmus PE (1993) Carboplatin as second line treatment for recurrent or progressive brain metastases from small cell lung cancer. Eur J Cancer 29A: 1696-1699

Gronberg BH, Bremnes RM, Aasebo U, Brunsvig P, Flotten O, Amundsen T, von Plessen C, Wang M, Sundstrom S (2008) A prospective phase II study: high-dose pemetrexed as second-line chemotherapy in small-cell lung cancer. Lung Cancer 63: 88-93

Hanna N, Bunn Jr PA, Langer C, Einhorn L, Guthrie Jr T, Beck T, Ansari R, Ellis P, Byrne M, Morrison M, Hariharan S, Wang B, Sandler A (2006a) Randomized phase III trial comparing irinotecan/cisplatin with etoposide/cisplatin in patients with previously untreated extensive-stage disease small-cell lung cancer. J Clin Oncol 24: 2038-2043

Hanna NH, Ansari R, Bhatia S, Govindan R, Bruetman D, Hosford M, Fisher W, White A, Breen T, Juliar B (2006b) Pemetrexed in patients (pts) with relapsed small cell lung cancer (SCLC): a phase II study from the Hoosier Oncology Group. J Clin Oncol 24. Abstract 7063

Heigener DF, Freitag L, Eschbach C, Huber RM, Fink T, Hummler S, Banik N, Wolf M (2008) Topotecan/cisplatin (TP) compared to cisplatin/ etoposide (PE) for patients with extensive disease-small cell lung cancer (ED- SCLC): final results of a randomised phase III trial. J Clin Oncol 26 Abstract 7513

Hermes A, Bergman B, Bremnes R, Ek L, Fluge S, Sederholm C, Sundstrøm S, Thaning L, Vilsvik J, Aasebø U, Sörenson S (2008) Irinotecan plus carboplatin versus oral etoposide plus carboplatin in extensive small-cell lung cancer: a randomized phase III trial. J Clin Oncol 26: 4261-4267

Hoang T, Kim K, Jaslowaski A, Koch P, Beatty P, McGovern J, Quisumbing M, Shapiro G, Witte R, Schiller JH (2003) Phase II Study of second-line gemcitabine in sensitive or refractory small cell lung cancer. Lung Cancer 42: $97-102$

Huncharek M, McGarry R (2004) A meta-analysis of the timing of chest irradiation in the combined modality treatment of limited-stage small cell lung cancer. Oncologist 9: 665-672

Inoue A, Sugawara S, Yamazaki K, Maemondo M, Suzuki T, Gomi K, Takanashi S, Inoue $\mathrm{C}$, Inage $\mathrm{M}$, Yokouchi $\mathrm{H}$, Watanabe $\mathrm{H}$, Tsukamoto $\mathrm{T}$, Saijo Y, Ishimoto O, Hommura F, Nukiwa T (2008) Randomized phase II trial comparing amrubicin with topotecan in patients with previously treated small-cell lung cancer: North Japan Lung Cancer Study Group Trial 0402. J Clin Oncol 26: 5401-5406

Jalal SI, Bhatia S, Einhorn LH, Ansari RH, Bechar N, Govindan R, Koneru K, Bedano PM, Wu J, Hanna NH (2008) Paclitaxel (P) plus bevacizumab (B) in patients (pts) with chemosensitive relapsed small cell lung cancer (SCLC): a safety, feasibility and efficacy trial from the Hoosier Oncology Group. J Clin Oncol 26. Abstract 19103

Jassem j, Karnicka-Mlodkowska H, van Pottelsberghe C, van Glabbeke M, Noseda MA, Ardizzoni A, Gozzelino F, Planting A, van Zandwijk N, EORTC Lung Cancer Cooperative Group (1993) Phase II study of vinorelbine (Navelbine) in previously treated small cell lung cancer patients. Eur J Cancer 29A: 1720 - 1722

Johl J, Chansky K, Lara PN, Davies AM, Bold R, Gandara DR (2005) The proteasome inhibitor PS-341 (Bortezomib) in platinum (plat)-treated extensive-stage small cell lung cancer (E-SCLC): a SWOG (0327) phase II trial. J Clin Oncol 23. Abstract 7047
Joos G, Schallier D, Pinson P, Sterckx M, Van Meerbeeck JP (2004) Paclitaxel (PTX) as second line treatment in patients (pts) with small cell lung cancer (SCLC) refractory to carboplatin-etoposide: a multicenter phase II study. Proc Am Soc Clin Oncol (Abstr 7211)

Johnson BE, Fischer T, Fischer B, Dunlop D, Rischin D, Silberman S, Kowalsaki MO, Sayles D, Dimitrijevic S, Fletcher C, Hornick J, Salgia R, Le Chevalier T (2003) Phase II study of imatinib in patients with small cell lung cancer. Clin Cancer Res 9(16 Pt 1): 5880-5887

Kato T, Nokihara H, Ohe Y, Yamamoto N, Sekine I, Kunitoh H, Kubota K, Nishiwaki Y, Saijo N, Tamura T (2006) Phase II trial of amrubicin in patients with previously treated small cell lung cancer (SCLC). J Clin Oncol 24. Abstract 7061

Kim YH, Goto K, Yoh K, Niho S, Ohmatsu H, Kubota K, Saijo N, Nishiwaki Y (2008) Performance status and sensitivity to first-line chemotherapy are significant prognostic factors in patients with recurrent small cell lung cancer receiving second-line chemotherapy. Cancer 113: $2518-2523$

Krug LM, Crapanzano JP, Azzoli CG, Miller VA, Rizvi N, Gomez J, Kris MG, Pizzo B, Tyson L, Dunne M, Heelan RT (2005) Imatinib mesylate lacks activity in small cell lung carcinoma expressing c-kit protein: a phase II clinical trial. Cancer 103: $2128-2131$

Kudoh S, Yoshimura N, Kimura T, Mitsuoka S, Hirata K (2006) A phase II trial of amrubicin (AMR) for recurrent or refractory small cell lung cancer (SCLC). J Clin Oncol 24. Abstract 17053

Lad T, Piantadosi S, Thomas P, Payne D, Ruckdeschel J, Giaccone G (1994) A prospective randomized trial to determine the benefit of surgical resection of residual disease following response of small cell lung cancer to combination chemotherapy. Chest 106: $320 \mathrm{~S}-323 \mathrm{~S}$

Lally BE, Urbanic JJ, Blackstock AW, Miller AA, Perry MC (2007) Small cell lung cancer: have we made any progress over the last 25 years? Oncologist 12: $1096-1104$

Lara Jr PN, Natale R, Crowley J, Lenz HJ, Redman MW, Carleton JE, Jett J, Langer CJ, Kuebler JP, Dakhil SR, Chansky K, Gandara DR (2009) Phase III trial of irinotecan/cisplatin compared with etoposide/cisplatin in extensive-stage small-cell lung cancer: clinical and pharmacogenomic results from SWOG S0124. J Clin Oncol 27: 2530-2535

Lee SM, James LE, Qian W, Spiro S, Eisen T, Gower NH, Ferry DR, Gilligan D, Harper PG, Prendiville J, Hocking M, Rudd RM (2009) Comparison of gemcitabine and carboplatin versus cisplatin and etoposide for patients with poor-prognosis small cell lung cancer. Thorax 64(1): $75-80$

Lee SM, James L, Buchler T, Snee M, Ellis P, Hackshaw A (2008) Phase II trial of thalidomide with chemotherapy and as maintenance therapy for patients with poor prognosis small-cell lung cancer. Lung Cancer 59: $364-368$

Lee SM, Woll PJ, Rudd R, Ferry D, O'Brien M, Middleton G, Spiro S, James L, Ali K, Jitlal M, Hackshaw A (2009) Anti-angiogenic therapy using thalidomide combined with chemotherapy in small cell lung cancer: a randomized, double-blind, placebo-controlled trial. J Natl Cancer Inst 101(15): $1049-1057$

Lim E, Goldstraw P (2008) Surgery as primary treatment for limited disease small cell lung cancer: time to re-evaluate. J Clin Oncol 25. Abstract 7719

Masters GA, Declerck L, Blanke C, Sandler A, DeVore R, Miller K, Johnoson D, Eastern Cooperative Group (2003) Phase II trial of gemcitabine in refractory or relapsed small-cell lung cancer: Eastern Cooperative Oncology Group Trial 1597. J Clin Oncol 21: $1550-1555$

Masuda N, Fukuoka M, Kusunoki Y, Matsui K, Takifuji N, Kudoh S, Negoro S, Nishioka M, Nakagawa K, Takada M (1992) CPT-11: a new derivative of camptothecin for the treatment of refractory or relapsed small-cell lung cancer. J Clin Oncol 10: 1225-1229

Mavroudis D, Papadakis E, Veslemes M, Tsiafaki X, Stavrakakis J, Kouroussis C, Kakolyris S, Bania E, Jordanoglou J, Agelidou M, Vlachonicolis J, Georgoulias V (2001) A multicenter randomized clinical trial comparing paclitaxel-cisplatin-etoposide versus cisplatin-etoposide as first-line treatment in patients with small-cell lung cancer. Ann Oncol 12: $463-470$

Moore AM, Einhorn LH, Estes D, Govindan R, Axelson J, Vinson J, Breen TE, Yu M, Hanna NH (2006) Gefitinib in patients with chemo-sensitive and chemo-refractory relapsed small cell cancer: a Hoosier Oncology Group phase II trial. Lung Cancer 52: 93-97

NCCN (2008) Small cell lung cancer. In NCCN Clinical Practice Guidelines in Oncology V. 2010. www.nccn.org

Nicum SJ, O'Brien ME (2007) Topotecan for the treatment of small-cell lung cancer. Expert Rev Anticancer Ther 7: 795-801 
Niell HB, Herndon 2nd JE, Miller AA, Watson DM, Sandler AB, Kelly K, Marks RS, Perry MC, Ansari RH, Otterson G, Ellerton J, Vokes EE, Green MR (2005) Randomized phase III intergroup trial of etoposide and cisplatin with or without paclitaxel and granulocyte colony-stimulating factor in patients with extensive-stage small-cell lung cancer: Cancer and Leukemia Group B Trial 9732. J Clin Oncol 23: 3752-3759

Niho S, Kubota K, Yoh K, Goto K, Ohmatsu H, Saijo N, Nishiwaki Y (2008) Clinical outcome of chemoradiotherapy in patients (pts) with limiteddisease small-cell lung cancer (LD-SCLC) with ipsilateral pleural effusion. J Clin Oncol 26. Abstract 7524

Noda K, Nishiwaki Y, Kawahara M, Negoro S, Sugiura T, Yokoyama A, Fukuoka M, Mori K, Watanabe K, Tamura T, Yamamoto S, Saijo N (2002) Irinotecan plus cisplatin compared with etoposide plus cisplatin for extensive small-cell lung cancer. $N$ Engl J Med 346: 85-91

O'Brien ME, Ciuleanu TE, Tsekov H, Shparyk Y, Cucevia B, Juhasz G, Thatcher N, Ross GA, Dane GC, Crofts T (2006) Phase III trial comparing supportive care alone with supportive care with oral topotecan in patients with relapsed small-cell lung cancer. J Clin Oncol 24: 5441-5447

Ohe Y, Negoro S, Matsui K, Nakagawa K, Sugiura T, Takada Y, Nishiwaki Y, Yokota S, Kawahara M, Saijo N, Fukuoka M, Ariyoshi Y (2005) Phase I-II study of amrubicin and cisplatin in previously untreated patients with extensive-stage small-cell lung cancer. Ann Oncol 16: 430-436

Okamoto H, Watanabe K, Kunikane H, Yokoyama A, Kudoh S, Asakawa T, Shibata T, Kunitoh H, Tamura T, Saijo N (2007) Randomised phase III trial of carboplatin plus etoposide $v s$ split doses of cisplatin plus etoposide in elderly or poor-risk patients with extensive disease smallcell lung cancer: JCOG 9702. Br J Cancer 97: 162 - 169

Onoda S, Masuda N, Seto T, Eguchi K, Takiguchi Y, Isobe H, Okamoto H, Ogura T, Yokoyama A, Seki N, Asaka-Amano Y, Harada M, Tagawa A, Kunikane H, Yokoba M, Uematsu K, Kuriyama T, Kuroiwa Y, Watanabe K (2006) Phase II trial of amrubicin for treatment of refractory or relapsed small-cell lung cancer: Thoracic Oncology Research Group Study 0301. J Clin Oncol 24: 5448-5453

Pignon JP, Arriagada R, Ihde DC, Johnson DH, Perry MC, Souhami RL, Brodin O, Joss RA, Kies MS, Lebeau B (1992) A metaanalysis of thoracic radiotherapy for small-cell lung cancer. $N$ Engl J Med 327: $1618-1624$

Pijls-Johannesma MC, De Ruysscher D, Lambin P, Rutten I, Vansteenkiste JF (2005) Early versus late chest radiotherapy for limited stage small cell lung cancer. Cochrane Database Syst Rev CD004700

Popat S, O'Brien M (2005) Chemotherapy strategies in the treatment of small cell lung cancer. Anticancer Drugs 16(4): 361-372

Postmus PE, Haaxma-Reiche H, Gregor A, Groen HJ, Lewinski T, Scolard T, Kirkpatrick A, Curran D, Sahmoud T, Giaccone G (1998) Brain-only metastases of small cell lung cancer; efficacy of whole brain radiotherapy. An EORTC phase II study. Radiother Oncol 46: 29-32

Postmus PE, Haaxma-Reiche H, Sleijfer DT, Kirkpatrick A, McVie JG, Kleisbauer JP (1989) High dose etoposide for brain metastases of small cell lung cancer. A phase II study. The EORTC Lung Cancer Cooperative Group. Br J Cancer 59: 254-256

Postmus PE, Haaxma-Reiche H, Smit EF, Groen HJ, Karnicka H, Lewinski T, van Meerbeeck J, Clerico M, Gregor A, Curran D, Sahmoud T, Kirkpatrick A, Giaccone G (2000) Treatment of brain metastases of small-cell lung cancer: comparing teniposide and teniposide with wholebrain radiotherapy - a phase III study of the European Organization for the Research and Treatment of Cancer Lung Cancer Cooperative Group. J Clin Oncol 18: $3400-3408$

Postmus PE, Smit EF, Haaxma-Reiche H, van Zandwijk N, Ardizzoni A, Quoix E, Kirkpatrick A, Sahmoud T, Giaccone G (1995) Teniposide for brain metastases of small-cell lung cancer: a phase II study. European Organization for Research and Treatment of Cancer Lung Cancer Cooperative Group. J Clin Oncol 13: 660-665

Prophylactic-Cranial-Irradiation-Overview-Collaborative-Group (2000) Cranial irradiation for preventing brain metastases of small cell lung cancer in patients in complete remission. Cochrane Database Syst Rev 4: CD002805

Pujol JL, Breton JL, Gervais R, Tanguy ML, Quoix E, David P, Janicot H, Westeel V, Gameroff S, Geneve J, Maraninchi D (2007) Phase III doubleblind, placebo-controlled study of thalidomide in extensive-disease small-cell lung cancer after response to chemotherapy: an intergroup study FNCLCC cleo04 IFCT 00-01. J Clin Oncol 25: 3945-3951

Ramalingam SS, Mack PC, Vokes EE, Longmate J, Govindan R, Koczywas M, Ivy SP, Belani CP, Gandara DR (2008) Cediranib (AZD2171) for the treatment of recurrent small cell lung cancer (SCLC): A California Consortium phase II study (NCI. J Clin Oncol 26. Abstract 8078
Ready N, Dudek AZ, Wang XF, Graziano S, Green MR, Vokes EE (2007) CALGB 30306: a phase II study of cisplatin (C), irinotecan (I) and bevacizumab (B) for untreated extensive stage small cell lung cancer (ESSCLC). J Clin Oncol 25. Abstract 7563

Roth BJ, Johnson DH, Einhorn LH, Schacter LP, Cherng NC, Cohen HJ, Crawford J, Randolph JA, Goodlow JL, Broun GO (1992) Randomized study of cyclophosphamide, doxorubicin, and vincristine versus etoposide and cisplatin versus alternation of these two regimens in extensive small-cell lung cancer: a phase III trial of the Southeastern Cancer Study Group. J Clin Oncol 10: 282-291

Rudin CM, Salgia R, Wang X, Hodgson LD, Masters GA, Green M, Vokes EE (2008) Randomized phase II Study of carboplatin and etoposide with or without the bcl-2 antisense oligonucleotide oblimersen for extensivestage small-cell lung cancer: CALGB 30103. J Clin Oncol 26: 870-876

Sandler A, Szwaric S, Dowlati A, Moore DF, Schiller JH (2007) A phase II study of cisplatin (P) plus etoposide (E) plus bevacizumab (B) for previously untreated extensive stage small cell lung cancer (SCLC) (E3501): a trial of the Eastern Cooperative Oncology Group. J Clin Oncol 25. Abstract 7564

Schneider BJ et al. (2006) Phase II trial of imatinib maintenance therapy after irinotecan and cisplatin in patients with c-kit positive extensivestage small cell lung cancer(ES SCLC). J Clin Oncol 2006. ASCO Annual Meeting Proceeding Part 1 24(18S): 17089

Shepherd FA, Crowley J, Van Houtte P, Postmus PE, Carney D, Chansky K, Shaikh Z, Goldstraw P (2007) The International Association for the Study of Lung Cancer lung cancer staging project: proposals regarding the clinical staging of small cell lung cancer in the forthcoming (seventh) edition of the tumor, node, metastasis classification for lung cancer. J Thorac Oncol 2: 1067-1077

Skarlos DV, Samantas E, Kosmidis P, Fountzilas G, Angelidou M, Palamidas P, Mylonakis N, Provata A, Papadakis E, Klouvas G, Theocharis D, Panousaki E, Boleti E, Sphakianoudis G, Pavlidis N, for the Lung Cancer Study Group (1994) Randomized comparison of etoposide-cisplatin $v s$. etoposide-carboplatin and irradiation in small-cell lung cancer. A Hellenic Co-operative Oncology Group study. Ann Oncol 5: $601-607$

Slotman B, Faivre-Finn C, Kramer G, Rankin E, Snee M, Hatton M, Postmus P, Collette L, Musat E, Senan S (2007) Prophylactic cranial irradiation in extensive small-cell lung cancer. $N$ Engl J Med 357: 664-672

Smit EF, Fokkema E, Biesma B, Groen HJ, Snoek W, Postmus PE (1998) A phase II study of paclitaxel in heavily pretreated patients with small-cell lung cancer. Br J Cancer 77: 347-351

Socinski MA, Raju RN, Neubauer M, Smith DA, Richards DA, Savin M, Ruxer RL, Reynolds CH, Zhan F, Bromund JL, Chen R, Obasaju C (2008) Pemetrexed in relapsed small-cell lung cancer and the impact of shortened vitamin supplementation lead-in time: results of a phase II trial. J Thorac Oncol 3: $1308-1316$

Socinski MA, Smit EF, Lorigan P, Konduri K, Reck M, Szczesna A, Blakely J, Serwatowski P, Karaseva NA, Ciuleanu T, Jassem J, Dediu M, Hong S, Visseren-Grul C, Hanauske AR, Obasaju CK, Guba SC, Thatcher N (2009) Phase III study of pemetrexed plus carboplatin compared with etoposide plus carboplatin in chemotherapy-naive patients with extensive-stage small-cell lung cancer. J Clin Oncol 27: 4787-4792

Socinski MA, Stinchcombe TE (2007) Duration of first-line chemotherapy in advanced non small-cell lung cancer: less is more in the era of effective subsequent therapies. J Clin Oncol 25: 5155-5157

Spigel DR, Hainsworth JD, Simons L, Meng C, Burris III HA, Yardley DA, Grapski R, Schreeder M, Mallidi PV, Greco FA, Minnie Pearl Cancer Research Network (2007) Irinotecan, carboplatin, and imatinib in untreated extensive-stage small-cell lung cancer: a phase II trial of the Minnie Pearl Cancer Research Network. J Thorac Oncol 2: 854-861

Stahel RA, Ginsberg R, Havemann K, Hirsch FR, Ihde DC, Jassem J (1989) Staging and prognostic factors in small cell lung cancer; a consensus report. Lung Cancer 5: 119-126

Sundstrom S, Bremnes RM, Kaasa S, Aasebo U, Aamdal S (2005) Secondline chemotherapy in recurrent small cell lung cancer. Results from a crossover schedule after primary treatment with cisplatin and etoposide (EP-regimen) or cyclophosphamide, epirubicin, and vincristin (CEVregimen). Lung Cancer 48: 251-261

Sundstrom S, Bremnes RM, Kaasa S, Aasebo U, Hatlevoll R, Dahle R, Boye N, Wang M, Vigander T, Vilsvik J, Skovlund E, Hannisdal E, Aamdal S (2002) Cisplatin and etoposide regimen is superior to cyclophosphamide, epirubicin, and vincristine regimen in small-cell lung cancer: results from a randomized phase III trial with 5 years' follow-up. J Clin Oncol 20: $4665-4672$ 
Turrisi 3rd AT, Kim K, Blum R, Sause WT, Livingston RB, Komaki R, Wagner H, Aisner S, Johnson DH (1999) Twice-daily compared with once-daily thoracic radiotherapy in limited small-cell lung cancer treated concurrently with cisplatin and etoposide. $\mathrm{N} \mathrm{Engl} \mathrm{J}$ Med 340: $265-271$

van der Lee I, Smit EF, van Putten JW, Groen HJ, Schlösser NJ, Postmus PE, Schramel FM (2001) Single-agent gemcitabine in patients with resistant small-cell lung cancer. Ann Oncol 12: $557-561$

Vincent M, Evans B, Smith I (1988) First-line chemotherapy rechallenge after relapse in small cell lung cancer. Cancer Chemother Pharmacol 21: $45-48$

von Pawel J, Gatzemeier U, Pujol JL, Moreau L, Bildat S, Ranson M, Richardson G, Steppert C, Riviere A, Camlett I, Lane S, Ross G (2001) Phase ii comparator study of oral versus intravenous topotecan in patients with chemosensitive small-cell lung cancer. J Clin Oncol 19: $1743-1749$

von Pawel J, Schiller JH, Shepherd FA, Fields SZ, Kleisbauer JP, Chrysson NG, Stewart DJ, Clark PI, Palmer MC, Depierre A, Carmichael J, Krebs JB, Ross G, Lane SR, Gralla R (1999) Topotecan versus cyclophosphamide, doxorubicin, and vincristine for the treatment of recurrent small-cell lung cancer. J Clin Oncol 17: 658-667

Warde P, Payne D (1992) Does thoracic irradiation improve survival and local control in limited-stage small-cell carcinoma of the lung? A metaanalysis. J Clin Oncol 10: 890-895

Yau T, Ashley S, Popat S, Norton A, Matakidou A, Coward J, O'Brien ME (2006) Time and chemotherapy treatment trends in the treatment of elderly patients (age $>I=70$ years) with small cell lung cancer. $\mathrm{Br} J$ Cancer 94: $18-21$ 